\title{
UNDERSTANDING INSURGENT MARGINS IN KENYA, NIGERIA AND MALI
}

In recent years, violent insurgency has gripped the margins of Kenya, Mali and Nigeria. Militant Islamist groups have attacked civilian populations, state security personnel and political-administrative officials, spreading insecurity across large areas and exploiting the mistrust between societies at the margins and central authorities. More attention needs to be focused on the role of local political, economic and social conditions in the areas where attacks are taking place, and a long-term solution to addressing violence in each country must involve resolving long-standing political grievances, a legacy of past state violence towards minority populations, and intra-regional inequality.

\section{Widening violence in Kenya, Nigeria and Mali}

Over the past decade, violence has bubbled away at the margins of a number of sub-Saharan African countries. Militant groups in Kenya, Mali and Nigeria share a similar self-proclaimed ideology, concerned with the introduction or imposition of Islamist policies, laws and customs, and the use of violent force in pursuit of these goals. This brief focuses on the drivers of this violence, its relationship to the state and its exercise of power, and the interactions with other forms of conflict in each country, and not the ideological and doctrinal content of these groups' agendas.

$\square$
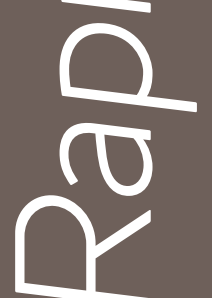

Escalating attacks by militants, alongside copy-cat attacks and vendetta veiled as violence, have roiled the often rural hinterlands of Kenya, Nigeria and Mali. From bombed marketplaces and public buses, to village massacres and mass kidnappings of schoolchildren, the devastating reach of this violence has upended lives and livelihoods across large areas of all three countries. Violence peaked in Mali in 2012-2013, with over half a million people in the country's north either displaced or fleeing to neighbouring countries. Clashes between rival armed forces were also accompanied by violence by Malian soldiers against civilians, as French forces advanced, inadvertently providing cover for the Malian army. Violence initially increased following the French-led military intervention, before falling from mid-2013 onwards, paving the way for a political agreement between the Malian government and predominantly Tuareg rebels. Yet, 100,000 people were still displaced as of January 2015, and ongoing, lower-intensity violence involving both communal and religiously-framed violence persists. Nigeria's National Emergency Management Authority estimates that more than 1.2 million people have been displaced during the ongoing Jama'at Ahl as-Sunnah lid-Da'wah wa'I-Jihad (commonly and hereafter referred to as 'Boko Haram') insurgency in northern Nigeria, while hundreds have been killed in attacks associated with Al-Shabaab in Kenya. With violence spiking in both Kenya and Nigeria in 2014, governments there have struggled to respond to a political crisis rooted in sociological transformation. The Kenyan and Nigerian governments have stepped up military operations. While these may yet push militants out of strategic centres and towns, they do not address the roots of spreading insurgency.

\section{What is driving this violent insurgency?}

The expanding reach of violence by militant Islamic organisations in sub-Saharan Africa is often viewed through the prism of transnational jihadism and international concerns around terrorism. Security analysts refer to an 'arc of instability' - 'Sahelistan' in the words of French Foreign Minister Laurent Fabius - extending from Mali westwards across the Sahel, stretching all the way to Somalia in the Horn of Africa, with spillover effects from countries further north including Libya and Algeria. Such concepts conjure a region of violent insurgencies and networks of interlinked militant Islamic groups, like Al Qaeda in the Islamic Maghreb (AQIM), the Movement for Oneness and Jihad in West Africa (MUJAO), Boko Haram in Nigeria and Al-Shabaab in Somalia. The March 2015 statement by Boko Haram leader Abubakar Shekau pledging allegiance to the Islamic State in Iraq and the Levant renewed fears of alliance building among militant groups. 
The emphasis on transnational connectivity conceals the complex socio-historical conditions and internal contradictions driving violence. On closer inspection a series of discrete insurgencies steeped in long-existing divisions between the centre and societies at the margins, alongside sub-national rivalries and inequalities entwining with these macrocleavages is revealed. The mobilisation of collective violence under a specifically Islamist identity mantle at this point in time reflects the influence of transnational and global trends in rendering this identity a salient basis for violent conflict. However, the history and legacies of distinct forms of violent conflict in each country undermine the notion that this violence is a critical rupture in the histories and politics of each state. Local grievances, mapped onto highly politicised regional and religious identities, can account for the simultaneous rise of violence in such diverse contexts. Critically, the sustainable resolution of these violent conflicts involves the recognition of these historical grievances.

With minimal resources, Al-Shabaab has unsettled Kenya's domestic politics, deftly picking at regional and ethnic divisions as well as exploiting long-standing rifts between the state and various societies in north-eastern and coastal areas of the country. A long history of state violence as well as armed insurgency precedes rising violent insecurity in Kenya's north-eastern region. The state fought an indiscriminate counter-insurgency against Somali secessionist Shifta rebels in the 1960s, including forced villagisation. Four thousand died during the conflict. The North Eastern Province as it was then known continued to be governed under a restrictive emergency regime until 1991. A number of massacres by state agents were carried out during this time, including the reported killing of thousands at the Wagalla airstrip in 1984. Other aspects of militarisation in north-eastern Kenya included a 1989 screening exercise and deportations of Somalis suspected of being in Kenya illegally, swoops by security services on Somali neighbourhoods and towns, and requirements that Kenyan Somalis obtain and carry additional identity cards.

The state's policy of exclusion and 'othering' refracts differently but no less powerfully in Kenya's coastal counties, where violence and politics are closely interwoven. Marginalisation and contested land rights animate the region's divided politics, with an estimated 80 per cent of the coast's indigenous population lacking title to land. Pwani si Kenya - 'the Coast is not Kenya', the motto of the outlawed coast secessionist group the Mombasa Republican Council (MRC), evokes a different type of 'margins' produced over generations through Nairobi's exclusionary political and economic practices. While there are no formalised links between the MRC and Al-Shabaab, the region's history of under-development is a tableau against which the spread of violent insecurity comes into stark relief.

The case of northern Mali provides another example of the cyclical nature of violence in precisely the same spaces in which contemporary violent groups have subsequently operated. Violence in the region dates from the process of decolonisation, when hopes for the creation of a new political unit in the Tuareg-inhabited areas of the Sahara were not realised, and an embryonic revolt in 1963 was crushed by the Malian government. The growing development gap between the north and south - reflected in the devastating 1971-73 famine - fed into revolts in 1990 and 2006. More recently, while violence levels have declined from their 2012-13 peak, it has not abated entirely, with persistent militant attacks continuing, including the March 2015 bombing of a Bamako nightclub, showing the capacity of militants to attack at the centre.

In these volatile conditions, 2014 witnessed the return to hostilities between ethnically mobilised, predominantly Tuareg militants, pro-government militias and security forces, at the same time a series of peace negotiations in Algeria aimed at bringing an end to decades of recurring violence in the far north of the country. These factors attest to the interconnectedness of previous forms of violent opposition, contemporary violence, and wider instability which continue to characterise the situation in Mali today. 
Northern Nigeria's recent history is also characterised by violent conflict and cycles of religiously-framed militancy. These include the Maitatsine riots in several northern states in the early 1980s, which were violent manifestations of Islamic revivalism. The violence that accompanied the introduction of and opposition to Sharia law in 2000 and 2001 in 12 northern states reflected the mobilisation of violence not only along familiar Christian-Muslim fault lines, but also intra-Muslim divisions concerning the role and interpretation of religious teachings and texts in political and social life.

Thus, the longue durée of regional insecurity in the three states shows that recent violence is not, in fact, a critical rupture with past patterns of violence but, rather, builds on earlier cycles of unrest and state violence.

\section{Jihad's political turn}

The greatest threat from militant organisations in all three countries lies in how they exploit widely-held feelings of disaffection at the margins. The states' failings over time to address deeply-rooted marginalisation and insecurity in these places, and their use of repressive machinery to respond to insurgencies, provide the foundation for violence to recur.

Al-Shabaab is deft at weaving together local grievances with the politics of Kenya's military involvement in Somalia. Claiming responsibility for a June 2014 attack in Mpeketoni - a settlement scheme in coastal Lamu County established in the 1960s for Gikuyu from the central highlands - a statement by the group explained that Mpeketoni 'was originally a Muslim town before it was invaded and occupied by Christian settlers', adding that the attack was 'revenge for the presence of Kenyan troops in Somalia and the killing of Muslims'. Al-Shabaab has further permeated Kenya's already incendiary politics even while insecurity worsens. Kenya's President Uhuru Kenyatta blamed the Mpeketoni attack on local political networks even though Al-Shabaab claimed responsibility. Picking up the cue, other cabinet officials and policing officials blamed opposition figures.

Still, the government's security responses - ranging from large-scale policing operations in Somali neighbourhoods to new security legislation - dovetail with an unseemly politicisation of worsening violence. The unlawful killings of several prominent Muslim clerics in Mombasa - attributed by some community members as well as human rights observers to Kenya's AntiTerrorism Police Unit - underscore the particularly hostile relationship between the state and coastal populations, and reinforce perceptions of the discriminatory and violent way the state is seen to exercise power and control.

Boko Haram violence, and the current response to it, is conditioned in part by a profoundly weakened relationship between populations in the affected areas and the state security forces. Human rights advocates have accused the Nigerian military and aligned paramilitary forces of extrajudicial killings and excessive force in their pursuit of suspected militants. Persistent accusations that the governing regime has lacked the political will to tackle Boko Haram because the group has primarily targeted northern populations (where the opposition has much of its support) reflect the breakdown in this relationship. Communities themselves in all three countries often face an impossible choice between security agencies which they do not entirely trust, and a militant group which preys upon them. In Nigeria, this security dilemma has culminated in the establishment of local vigilante units to tackle Boko Haram, with the tacit acceptance and occasional support of the government. The Civilian Joint Task Force is itself implicated in human rights abuses and indiscriminate violence against suspected Boko Haram members, while potentially serving to exacerbate the vulnerability of civilian populations to retributive violence by militants.

Analysis and policy responses should also be more sensitive to intra-regional inequality. Kenya's 2010 Constitution laid the ground for political devolution as a way to redress regional inequalities and historic marginalisation, particularly of the country's north. The stakes for local political competition have risen sharply with significant public funds and powers devolved to new county-level governments. Violence that flared in some northern counties preceding and after the March 2013 elections centred on control of newly-created national and county-level offices (with parallels in Mali electoral violence in 2007). Tensions were greatest in counties with pointed majority-minority group divisions, such as Marsabit, Isiolo and Mandera. A March 2015 Al-Shabaab attack targeting the Mandera Governor's convoy showed the group's skill at exploiting simmering local divisions. The theme is also relevant to the case of Mali, where northern peripherality was supposed to be partly addressed through previous peace agreements with predominantly Tuareg separatists, but which were never fully implemented, and constituted at least one driver of recurring violence in the region. 
In Nigeria, the dynamic of northern marginalisation from a national centre is more complex, and reflects a shifting political settlement of the country which is not as pronounced in both other country cases. Nigeria's post-independence period has been characterised by the changing importance of northern, predominantly Muslim, and southern, predominantly Christian elites, in a rotation of power which reflects the highly politicised nature of (largely) overlapping regional and religious identities. The context, therefore, is not one of consistent historical exclusion of northern Muslim populations from networks of power, as is more evident in both Kenya and Mali. The fact that the first large-scale violent confrontation between Boko Haram and the security forces in 2009 occurred during the reign of a President Umaru Musa Yar'Adua, a Muslim from Katsina State, further underscores that the relationship between instability and northern marginalisation is not entirely linear.

Nevertheless, Nigeria's northern region is far from homogenous, and is characterised by high levels of intra-regional inequality. Narratives around Boko Haram often emphasise the north-south divide in Nigerian politics: while this is certainly one cleavage along which politics are divided, intra-northern inequality is also a prevalent theme in the statements issued by Boko Haram, and in the traction the group had among northern communities in its earlier days.

\section{Recommendations}

In order to strengthen security and understand and address the violent insurgency taking place in these countries there needs to be:

1. Greater sensitivity within analysis and policy responses to intra-regional inequality.

2. Increased attention focused on the 'localisation of jihad' rather than the broader global Islamic agenda, and how conflict is rooted in a longer struggle at the margins against forms of marginalisation and repression, which exist alongside various provincial rivalries and divisions.

3. More initiatives that promote bottom-up inclusive development that reach out to marginalised regional, religious and ethnic groups and address issues of inequality.

4. Concerted efforts to make the most of considerable opportunities in new governance arrangements including devolution to address both historic as well as emerging drivers of conflict and violence such as land and resource rights, and the radicalisation of young people.

5. An urgent move towards placing civilian protection at the core of security responses. Heavy-handed security approaches that appear to rely on ethnic or religious profiling, and abuses by the security forces including unlawful killings and house-to-house sweeps, risk even worse violence.

\section{Further reading}

Last, M. (2015) 'The Search for Security in Muslim Northern Nigeria', Africa 78: 41-63

Lind, J.; Mutahi, P. and Oosterom, M. ( (2015, forthcoming) Tangled Ties: Al-Shabaab and Political Volatility in Kenya, IDS Evidence Report, Brighton: IDS

Conflict data drawn from Armed Conflict Location and Event Data Project (ACLED), www.acleddata.com

Guichaoua, Y. (2014) 'Mali: the Fallacy of Ungoverned Spaces', Blog Post (accessed March 2015), Norwich: UEA

\section{Credits}

This Rapid Response Briefing was written by Jeremy Lind (IDS Research Fellow) and Caitriona Dowd (PhD student at University of Sussex). The opinions expressed are those of the author and do not necessarily reflect the views of IDS.

Readers are encouraged to quote and reproduce material from issues of Rapid Response Briefings in their own publication. In return,

IDS requests due acknowledgement and quotes to be referenced as above.

The material has been funded by UK aid from the UK Government. However the views expressed do not necessarily reflect the UK Government's official policies.

(C) Institute of Development Studies 2015

AG Level 2 Output ID: 272

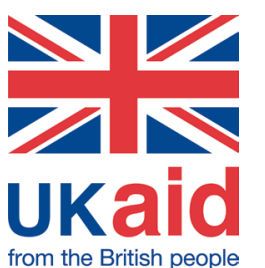

\section{Institute of Development Studies}

IDS Rapid Response Briefings are published by the Institute of Development Studies and aim to provide high-level analysis of rapidly emerging and unexpected global events and their impact on development policy and practice. To subscribe: www.ids.ac.uk/idsrapidresponsebriefings 